\title{
Designing Tasks for Complex Virtual Learning Environments
}

\author{
Malgorzata Kurek \\ Jan Dlugosz University, Czestochowa, Poland
}

Article received 10 May 2015, accepted 5 June 2015, final version 11 June 2015

DOI: http://dx.doi.org/10.5565/rev/jtl3.633

\begin{abstract}
The central role of tasks has long been acknowledged in foreign language pedagogy (e.g. Ellis, 2003; Willis, 1996; Müller-Hartmann \& Schocker, 2011), in the context of CALL (Furstenberg, 1997; Chapelle, 2001; Hampel, 2006; 2010; Levy \& Stockwell, 2006; Thomas \& Reinders, 2010) and, specifically, in literature on online collaboration (Dundis \& Benson, 2003; Gruba, 2004; Müller-Hartmann 2000; 2006; O’Dowd \& Ware, 2009; Guth \& Helm 2011; Dooly \& O'Dowd, 2012). In complex learning environments such as those of intercultural online exchanges (IOEs), the role of tasks is particularly pronounced as they drive and structure learners' activity in and through a complex, technology-rich multimodal, multilingual and multicultural context. In such an environment opportunities for learning are not obvious and need to be activated through adequate and relevant tasks. This article discusses the role of tasks in structuring learner activity in complex learning environments (CLEs), best exemplified by intercultural online exchanges (IOEs). First, the concept of complex learning environments (CLEs) are presented, followed by those aspects of task design that best address their complexity, including the role of tasks in executing teaching presence, the workplan-process dichotomy, the role of tasks in fostering community building, concluding with an overview of the mutual task-tool relationship and brief recommendations for training teachers in task design.
\end{abstract}

Keywords: task design, learning environment, community building, collaboration, teacher training

\section{Resumen}

Hace mucho tiempo se reconoce el papel importante que tienen las tareas en la didáctica de lenguas extranjeras (ver Ellis, 2003; Willis, 1996; MüllerHartmann \& Schocker, 2011), en el contexto de CALL (Furstenberg, 1997; Chapelle, 2001; Hampel, 2006; 2010; Levy \& Stockwell, 2006; Thomas \& Reinders, 2010) y, en particular, en la literatura sobre la colaboración en línea (telecolaboración) (ej. Dundis \& Benson, 2003; Gruba, 2004; Müller-Hartmann 2000; 2006; O'Dowd \& Ware, 2009; Guth \& Helm 2011; Dooly \& O'Dowd, 2012). En ambientes de aprendizaje complejos, como los de los intercambios interculturales en línea (IEL o Online Intercultural Exchange (OIE) en inglés), el papel de las tareas es particularmente pronunciado, ya que promueven y estructuran la actividad de los alumnos a través de un contexto altamente complejo por sus características tecnológicas, multimodales, multilingües y 
multiculturales. En un entorno de este tipo las oportunidades para el aprendizaje no son siempre inmediatemente evidentes y deben ser activadas a través de tareas adecuadas y pertinentes. En este artículo se analiza el papel de las tareas para estructurar la actividad del alumnado en Entornos de Aprendizaje Complejos (EAC), lo cuales son mejor ejemplificados por los intercambios interculturales en línea (telecolaboración intercultural). En este artículo se presenta el concepto de entornos de aprendizaje complejos (EAC), los aspectos del diseño de las tareas que mejor abordan su complejidad, incluyendo la función de las tareas en la ejecución docente, la dicotomía entre plan de trabajo $\mathrm{y}$ proceso de trabajo, el papel de las tareas fomentar la construcción de 'comunidad', concluyendo con una visión general de la relación entre la tarea y las herramientas, concluyendo con breves recomendaciones para la formación de profesorado en el diseño de tareas para estos entornos complejos.

Palabras clave: diseño de tareas, el entorno de aprendizaje, la creación de comunidades, la colaboración, la formación del profesorado

\section{Streszczenie}

Zadania dydaktyczne od dawna znajdują się w centrum uwagi edukacji językowej (n.p. Ellis, 2003; Willis, 1996; Müller-Hartmann \& Schocker, 2011), zwłaszcza w kontekście kształcenie językowego wspomaganego komputerem (Furstenberg, 1997; Chapelle, 2001; Hampel, 2006; 2010; Levy \& Stockwell, 2006 Thomas \& Reinders, 2010) oraz tzw. e-współpracy (Dundis \& Benson, 2003; Gruba, 2004; Müller-Hartmann 2000; 2006; O’Dowd \& Ware, 2009; Guth \& Helm 2011; Dooly \& O’Dowd, 2012). W złożonych środowiskach uczenia się zadania pełnią rolę szczególną, bowiem stymulują aktywność uczestnika oraz nadają owej aktywności cel, kierunek i strukturę. Ma to ogromne znaczenie $\mathrm{w}$ środowsku w którym, $\mathrm{z}$ racji jego multimodalności, wielojęzyczności oraz wielokulturowości, możliwości uczenia się nie są dla uczestnika oczywiste. Niniejszy tekst omawia zadania dydaktyczne w kotekście interkulturowych wymian online. Po zarysowaniu pojęcia, prezentuję te aspekty zadań, które warunkują pracę ucznia: cechy dyskursywne instrukcji jako wyraz tzw. „teaching presence” (Anderson et al. 2001), zadanie-jako-plan oraz zadanie-jako-proces, rolę zadań w tworzeniu poczucia wspólnoty, oraz dwustronną zależność miedzy zadaniem i narzędziem. Tekst zamykają rekomendacje dla kształcenia nauczycieli.

Słowa kluczowe: zadanie dydaktyczne, środowisko uczenia się, wspólnota, wpółpraca, szkolenie nauczycieli 


\section{Introduction}

Learning tasks have been in the centre of didactic attention for the past 30 years, first as the pillars of the Task Based Learning (TBL) and then increasingly discussed in the context of computer-enhanced instruction. The essence of TBL can be traced back to the long-standing principle of "integral education" (see Doughty \& Long, 2003:58 for an overview) in which the learning process is tied to real-world practices and built around the skills and knowledge that learners develop and accumulate in the process of executing tasks. It is also through taskrelated performance that participants are prompted to step out of the prescribed learner roles and become language users immersed in an authentic (communicative) situation. In other words, task-induced learning is a by-product of learners' on-task activity rather than the focal point of instruction (Willis, 1996; Ellis, 2003; Doughty \& Long, 2003; Samuda \& Bygate, 2008).

Since its beginnings in early 80s, Task-Based Learning (and Teaching) has generated a rich and still expanding research literature reflecting different theoretical lenses from psycholinguistic (Long, 2000; Doughty \& Long, 2003), through cognitive (Skehan \& Foster, 2001, Robinson, 2001, 2011) to sociocultural (Hampel, 2006; Levy \& Stockwell, 2006; Müller- Hartmann \& Schocker-v.Ditfurth, 2010), and, finally, pedagogical (Willis, 1996; Ellis 2003, Nunan, 2004; Van den Branden, 2006; Samuda \& Bygate, 2008; Müller-Hartmann \& Schocker, 2011). Following, there emerged various interpretations of what constitutes a task. In the context of this paper, whose focus is on complex learning environments, I adopt a broad definition by Van den Branden (2006), who understands a task as an activity "in which a person engages in order to attain an objective, and which necessitates the use of language" (p. 4). One also needs to bear in mind the cornerstone TBL criteria suggested by Ellis (2003, pp. 9-10), namely that tasks are mere plans for learner activity; they are oriented towards meaning rather than form; bear resemblance to real-world practices, have potential for creating authentic experience and engage learners cognitively in the production of a "defined communication-based learning outcome" (Thomas \& Reinders, 2010, p. 2).

Technology mediation has had a fundamental impact of the conceptualisation of tasks. Despite initial attempts to simply transfer F2F tasks to the new environment (Hampel, 2006) it is clear now that technology-mediated learning environments have their unique affordances and contraints which, first, enable certain types of learner activity or discourse and, then, require suitable tasks to address them. Indeed, the role of pedagogy in guiding students' online activity has never been more apparent. As Gonzalez-Lloret (2014) asserts 
no matter how exciting new technologies or language learning may seem, they can become nothing more than entertainment unless their design, use, and evaluation are guided by viable educational and language developmental rationales. (p. 3)

This realisation has sharpened the perception of tasks the "pivotal components in [CALL] design" (p. 58) so that they now emerge as the main organizational units of leaners' online activity (Levy \& Stockwell, 2006, p. 16). Gruba (2004) warns that ignoring the principles of designing tasks for the new environment "may blunt pedagogical aims, confuse task writers, cause difficulties for learners and result in low task completion" (p. 72).

On a very practical level, technology mediation has helped to overcome those temporal and physical constraints of traditional classrooms which often stood in the way of successful task implementation (e.g. unequal participation, noise, mixed-ability groups or students' avoidance of L2 participation - see Lai \& Li, 2011 for an overview). Moreover it has given rise to a wide range of new types of multimodal interaction, be it with content or with other learners. Therefore Hauck (2010) argues that the activities designed for online contexts should first make appropriate use of multiple modalities and, then, also promote learners' digital literacy (see also Hampel, 2006; Levy \& Stockwell, 2006). As Hauck's arguments go "varying affordances require varying e-literacy skills (Ibid., p. 204).

Yet another research direction is the renewed scrutiny of criteria ensuring the appropriateness of CALL tasks. Initiated with Chapelle's SLA proposal (2001) in which she considered language learning potential as "the most critical for CALL activities", this research direction evolved to more integrated approaches based on sociocultural and pedagogical aspects (see Meskill, 1999; Dundis \& Benson, 2003; Doughty \& Long 2003; Hampel, 2006, 2010; Levy \& Stockwell, 2006; Jauregi, Canto, de Graaff, Koenraad \& Moonen, 2011, Müller-Hartmann \& Schocker, 2011; Kurek \& Müller-Hartmann, forthcoming). Particular consideration is being given to the criteria for assuring participatory, intercultural and collaborative learning, best realised in complex learning environments of Intercultural Online Exchanges (IOEs).

\section{Complex learning environments (CLEs)}

The principal role of tasks is to drive, guide and structure learners' activity in a given learning environment (Samuda \& Bygate, 2008). With more and more students' learning taking place in virtual and/or less formal conditions, the term learning environment is increasingly used to replace the traditional concept of a brick-and-mortar classroom. In the present discussion the label „complex" is added to address the pedagogical uniqueness of those learning 
environments in which the teacher needs to skilfully address "a large number of elements that interact with each other on physical as well as relational levels" (Cilliers, 1998). Complex learning environments can also be characterised by uncertainty, uniqueness, instability and potential conflicts (Müller-Hartmann, 2006). Human-Vogel \& Bouwer (2005) explain that the complexity of learning environments results from rich interactions among their elements, with each element influencing, and being influenced by a number of other elements. This sort of complexity reflects and is mutually related to the complexity of human learning and interaction as well as the processes of knowledge construction as seen from the sociocultural perspective.

CLEs are distinguished here in recognition of the challenges they pose to teachers in terms of course organization, delivery and pedagogy, task design being the focal factor involved. The concept of CLE should not be confused with that of task complexity as understood by Robinson (2001); complex tasks can be delivered in simple environments while complex environments may host a large number of simple tasks (see Robinson, 2001 for detailed specifications of task complexity). Moreover, the complexity of a learning environment is far from being an absolute value as it can be placed along a multidimensional continuum. The criteria may refer to the number of elements involved, density of interactions taking place or the number of communication channels or delivery options available to the participants. Furthermore, the concept of CLEs should not be restricted to online environments, although as Dervin (2013) puts it, they are

archetypical of unpredictability and uncertainty as interlocutors do not always see or hear each other and thus they have to rely on invented and/or reconfigured identities and representations. (Dervin, 2013, p. 194).

Thorne (2003) confirms that online contexts create "compelling, problematic, and surprising conditions for additional language learning” (p. 38). In general, the approach adopted here is that the greater the complexity of a learning environment, the more learning opportunities it may generate, if only learners' activity is framed with adequate tasks. In that we follow Human-Vogel and Bouwer's (2005) opinion that complex environments prompt new learning and the development of new patterns of behaviour whereas the predictable ones make learners merely "accumulate experiences" rather than respond to them (Human-Vogel, Bouwer, 2005, p. 236).

In brief, complex learning environments imply: 
- multitude - in the sense of a multitude of involved elements, be it tasks, participants, communication options or available mediation tools;

- variety and choice - participants may have a choice over communication modes and channels, types or order of activities, task procedures or task outcomes;

- unpredictability - tasks are complex enough to be open to various interpretations and realisations. The participants can initiate activity (e.g. social) or voice their opinion;

- interaction/communication density - participants are stimulated and have an opportunity to communicate and interact in various configurations and on different topics.

- instability - the diversity of available options and participants' motives may lead to tensions and contradictions or result in failed communication

Obviously, the above criteria do not exhaust the full range of characteristics nor do all of them need to be met. At the moment, CLEs seem to best represented by intercultural online exchanges (IOEs) and Massive Online Open Courses (MOOCs), the former being central to the current paper and used as the background for the following discussion of tasks.

Intercultural online exchanges, also known as telecollaboration or telecollaborative learning, are usually defined as "internet-based intercultural exchanges between groups of learners of different cultural/national backgrounds set up in an institutional blended-learning context" (Guth \& Helm 2011, p. 273). There is no exaggeration in the statement that such exchanges currently appear as the most complex and unpredictable CALL environments (O'Dowd, 2015), in which multi-layered and multi-channelled learning is enabled by immersing learners in authentic, multilingual, multicultural and technology-rich contexts. Pedagogical complexity of IOEs comes as a natural result of the dynamic (and thus unpredictable) interplay of geographical distance of participants and their resulting cultural and linguistic diversity, married to double technology and language mediation, collaborative format, as well participants' different linguistic and cultural backgrounds. What adds to the complexity of IOEs and increases the density of interactions is online cooperation of course instructors, which initiates and parallels that of the participating students.

Taken together, all those features make IOEs pedagogically complex and challenging. They also make the issue of task design a challenge for the IOE teachers, who should be able to strike balance between the multitude and diversity of the elements involved (e. g. the number of tools to be used or/and participants to be involved), the scope of choice given to the learners and the diversity of materials to interact with, yet at the same time scaffold 
learners' efforts in such a way that the intended learning objectives remain clear and achievable amidst the information noise of a new learning situation. Teaching presence which is needed to harness this environment is best voiced through pedagogical tasks and their instructions.

\section{Tasks and the teaching presence}

In a complex and ill-structured online environment, students' online activity needs to be guided for learning objectives to be achieved. It is tasks, artefacts, resources and interactions that create a reason for students' purposeful, cognitive online activity. Carefully crafted tasks serve as signposts to assist learners in becoming aware of available affordances and learning opportunities. In that sense tasks provide the "orchestration of meaning" (Kress, Jewitt, Osborne, \& Tsatsarelis, 2001) in a multimodal, multicultural, multiuser and multilingual environment. Oskoz and Elola (2014) demonstrate that a carefully sequenced selection of tasks not only guides learners through the process of collaborative writing but also assists them in the development of higher order thinking skills (Oskoz \& Elola, 2014, see also Ware \& O'Dowd, 2008). The research by Ortega proves that careful task design increases the frequency and complexity of student-to-student online interaction (Ortega, 2009). Lai \& Li (2011), having analysed a substantial body or research publications, confirm that in technology-mediated environments task design "demands attention to a much more context set of issues than designing tasks for F2F communication" (p. 507).

In practical terms, task procedures, their purpose and the final outcome are communicated to the learners through instructions. Ideally, their tone and wording should grasp learners' motivation and assure their cognitive investment in the task at hand. In that sense task instructions serve as a practical realisation of Anderson, Rourke, Garrison and Archer's (2000) notion of teaching presence (see also Garrison, 2006) that is "the design, facilitation, and direction of cognitive and social processes for the purpose of realizing personally meaningful and educationally worthwhile learning outcomes" (Anderson, et al., 2001, p. 5). As they affirm, “ it is only through active intervention of a teacher that a powerful communication tool (...) becomes a useful instructional and learning resource” (Ibid.).

In complex online environment teaching presence is mediated through all the available course materials, yet it seems most fully communicated through task instructions. Apart from simply communicating task content and procedures, task instructions may also compensate for the missing social context and include the discourse for maintaining social affiliation 
("Enjoy the project task", the use of emoticons), reducing technology anxiety ("It's an intuitive and user-friendly service") and managing task organization ("Deadline for task submission is ...”). Task instructions should also facilitate task execution by pointing to available support, be it technical (e.g. links to tutorials) linguistic (e.g. links to recommended dictionaries, reference sources or text models) or cognitive (e.g. suggesting a particular order of activities or the breaking of a task into smaller items). Table 1 below presents discursive features of sample task instructions delivered in a telecollaborative exchange between Polish and German teacher trainees.

Table 1. Voicing teaching presence through task instructions

\begin{tabular}{|c|c|}
\hline Discursive function & Discourse examples of task instructions \\
\hline Social affiliation & $\begin{array}{l}\text { Nourishing the community feel: } \\
\text { "Dear Students" } \\
\text { "Enjoy the project task }(-),\end{array}$ \\
\hline $\begin{array}{l}\text { Facilitation and } \\
\text { support (including } \\
\text { technology support) }\end{array}$ & $\begin{array}{l}\text { Reducing perceived difficulty } \\
\text { "It's a free, intuitive and user-friendly service." } \\
\text { Providing technical and pedagogical support } \\
\text { "Should you have any questions or doubts, consult them please with the teacher." } \\
\text { "A list of suggested tools with brief descriptions and relevant online tutorials is } \\
\text { available at the bottom of the current module." }\end{array}$ \\
\hline Task organization & $\begin{array}{l}\text { Setting the task in the context of the course/project } \\
\text { "Here is your first task." } \\
\text { "After having evaluated intercultural tasks, you are ready to start working on..." } \\
\text { Setting time parameters: } \\
\text { "Deadline for task submission is on Monday.", } \\
\text { Setting procedural parameters: } \\
\text { "Please use Canvas as your working tool." } \\
\text { "The final task should include the following elements:" } \\
\text { Work division: } \\
\text { "Polish students are requested to set up collaborations for their teams.", }\end{array}$ \\
\hline Task content & $\begin{array}{l}\text { Explaining the purpose: } \\
\text { "Design an intercultural activity which will help learners to get to know more about } \\
\text { the online partner." } \\
\text { "This is a major component of our course as it will help you consolidate what you've } \\
\text { learned so far." } \\
\text { Task mechanics (steps and procedures): } \\
\text { "Consider the age and the level of the group, the procedure, the tools used." } \\
\text { "Try to integrate different tools that allow learners to collaborate." } \\
\text { "Your assignment should meet the following criteria: (listed)" }\end{array}$ \\
\hline $\begin{array}{l}\text { Assessment and } \\
\text { follow-up } \\
\text { procedures }\end{array}$ & $\begin{array}{l}\text { "Remember that the task will be evaluated by your partner group." } \\
\text { "Both tasks and the feedback you give and receive will be further discussed in class." }\end{array}$ \\
\hline
\end{tabular}

As seen, carefully worded task instructions can compensate for lack of teacher-student proximity. They can also address and reinforce all the aspects of teaching presence (see 
Anderson, et al., 2001 for details) that is design and organization (by providing task procedures), discourse facilitation (by signalling social affiliation) and direct instruction (by pointing explain task content and pointing to task support). Following Lantolf and Thorne's division (2006, cited in Müller-Hartmann \& Schocker-v. Ditfurth, 2010), they may also inform students' performance on all the three levels of human activity that is activity itself (by addressing the sense of groupness or explaining the purpose of the task); action (by setting out task steps, procedures and specifying the final product); and, finally, on the level of operations by providing additional technical or pedagogical support to make up for participants' potentially missing competences. Careful wording can then help course instructors adjust the tasks to take into account learners' diverse backgrounds so that all of them are capable of achieving task outcome. In teacher training contexts, task instructions can additionally serve as models for learners' own task design (Kurek, Müller-Hartmann, forthcoming).

The complexity of an IOE as a learning environment can be to some extent facilitated through task sequencing (Doughty \& Long, 2003, O'Dowd \& Ware, 2009). When progressing through a series of increasingly complex pedagogic task, learners are prompted to build up the competences needed to achieve the target learning objectives. O'Dowd and Ware (2009) provide a widely used typology of tasks for online collaboration based on the type of communicative interaction they can stimulate and the depth of cognitive processes involved. The authors suggest three major areas for task categorisation and development namely: information exchange, comparison and analysis and product creation, the latter being the most demanding type of task. In long-term CLEs, students' activity can be, then, built around stages of increasing complexity, namely the introductory stage in which personal information is exchanged to build social bonds; a comparative stage which prompts analytical thinking and a stage of intense meaning negotiation in which the participants synthesize information and produce tangible products (Belz, 2002; Müller-Hartmann, 2007, O’Dowd \& Ware, 2009). Although created with telecollaborative exchanges in mind, the typology is universal enough to be used also in other CLEs, such as MOOCs. 


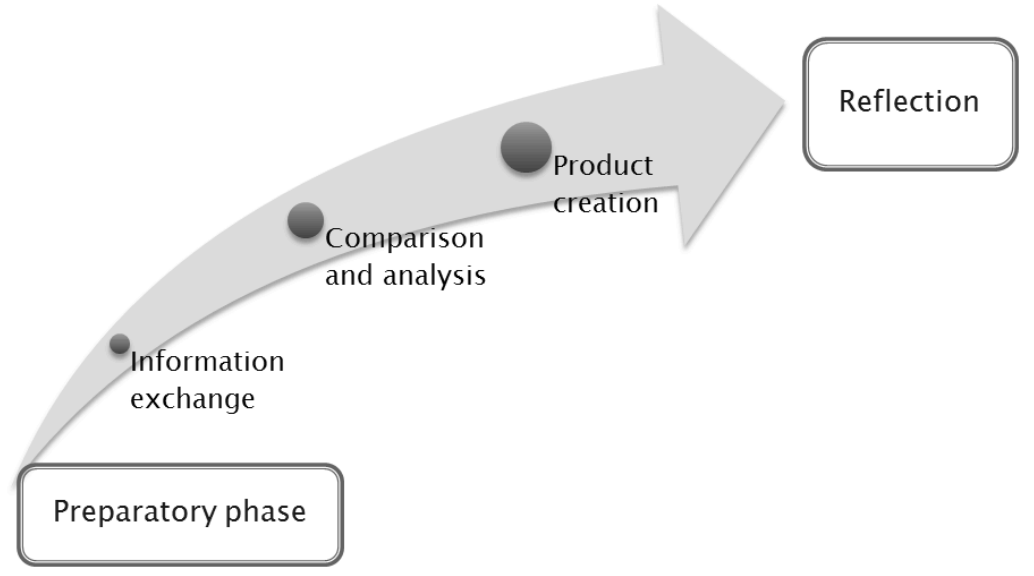

Figure 1. A model task progression in IOEs

Careful task structuring is also seen as a remedy to lack of correction and the missing focus on form, both of which are typically absent from TBL. There are suggestions that each of the tasks should be further broken down to include a 3-step cycle of pre-task, task and post-task, with the pre-task phase helping students prepare for task execution and post task hosting reflection, evaluation or correction acivities (Hampel, 2006; Helm \& Guth, 2010; Lai \&Li, 2011).

\section{Task as workplan}

Well structured and clearly communicated task instructions serve as a mere departure point for students' on-task performance, during which the task is interpreted in the light of students' needs, intentions, identities and their individual perceptions of the final goal. All of these factors work together towards modifications of teacher's task-as-plan (Müller-Hartmann \& Schocker v.Ditfurth 2010; Dooly, 2011) The amount of modification i.e. task-as-process will also depend on task openness. Loosely structured tasks, which tend to be associated with online environments, may "encourage learners to exercise agency and enact identities" (Lamy, 2007: 263). In general, however, even a well-structured task needs to be seen as a dynamic construct "in a constant state of negotiation", with each of the learners reconsidering and interpreting task requirements first through a personal filter and then in the process of group negotiation (see Breen, 1989 and Dooly, 2011 for more details). In a way, then, it can be said that tasks are subject to continuous adaptation: first in response to technology affordances, or students' changing perception of or experience with them (e.g. technical difficulties can make students reconsider task execution) and second, as a result of continuous tensions, negotiations and role distribution within a group. Müller-Hartmann and Kurek (forthcoming) point put that how tasks are performed may also depend on how the 
participants interpret them in light of their beliefs and former educational experiences. For example, teacher trainees whose dominant educational experience is that of a teacher-centred model will tend to design tasks implying a strong teacher control. The main reasons for varying task interpretations have been presented in Table 2 below.

Table 2. Students-generated reasons for task modifications

\begin{tabular}{lll}
\hline Factor & Reasons for possible task modifications (task-as-process) \\
\hline Technology & - & $\begin{array}{l}\text { learners' familiarity with technology affordance and constraints may not align } \\
\text { with task requirements.; } \\
\text { misinterpretation of tool affordances (e.g. in a task requiring collaboration } \\
\text { students may expect to be notified about the changes submitted by co-authors); } \\
\text { confusing tool's potential for supporting synchronous and asynchronous } \\
\text { communication. }\end{array}$ \\
\hline Social dynamics & - & $\begin{array}{l}\text { different perceptions of task goal and the final outcome. } \\
\text { - }\end{array}$ \\
\hline Linguistic resources & - & $\begin{array}{l}\text { communicative language resources may be inadequate to fully comprehend } \\
\text { task-as-workplan. }\end{array}$ \\
& - & $\begin{array}{l}\text { limited linguistic resources may breed avoidance strategies and lead to failed } \\
\text { communication }\end{array}$ \\
\hline Intercultural & - & $\begin{array}{l}\text { task instructions may be interpreted in light of one's own educational } \\
\text { experiences; } \\
\text { task procedures may be culturally interpreted (e.g. culturally approved (or not) } \\
\text { range of personal details to be disclosed to partners) }\end{array}$ \\
\hline
\end{tabular}

\section{Tasks and community building}

Sociocultural theories see learning as a predominantly community-based experience, for which it is crucial to build the feeling of trust and "groupness". Since in online contexts team members have never met or worked before, the dynamics of team performance are highly task-dependent (Chen, Wu, Yang, \& Tsou, 2008) as it takes a task to create a common purpose and help learners form a shared collective identity - the first step towards establishing social presence (Garrison, 2009). The feeling of belonging is beneficial as it helps reduce anxiety and sustain motivation throughout the project. Obviously, in IOEs group members represent diversified backgrounds therefore, as Lai and Li (2011) put it, successful task completion will be inevitably shaped by their "understanding and awareness of how their personal stories and sociocultural norms affect their own and their partners' task performance" (p. 510). Moreover, the activity of group members may be driven by various, internally or externally motivated intentions (see Kurek \& Müller-Hartmann, forthcoming) and be subject to the emerging relations of power. For instance, Müller-Hartmann and Schocker-v.Ditfirth (2010) observe that strong leadership may work counter to task specifications and significantly reduce student-to student interaction, whereas weak leadership will lead to evenly distributed participation. 
Importantly, in geographically distant groups whose participants may have very few shared identities, social presence rarely emerges out of its own accord and needs to be supported with the teaching one in form of tasks. For instance, the feeling of community can be built through ice-breaking information-exchange tasks in which learners are typically prompted to share their self-representations, be it verbal or multimodal. Such tasks make learners with diversified backgrounds first become aware of their own identities and, then, build trust and a community feel with other group members. Due to the fact that non-verbal communication cues are usually suppressed, trust is continuously built around group interactions through the tone and content of verbal messages (e.g. praising, crediting, showing interest) and through implicit management strategies such as timely communication, meeting deadlines or being transparent about one's intentions. Apart form the building of group trust and group cohesion, task members are likely to develop roles even if is has not been prescribed in task instructions (see Stockwell \& Levy 2001 for a typology of learner profiles). Such role division may emerge as a natural outcome of learners' competence- or personalityrelated strengths (Dundis \& Benson, 2030) and facilitate task execution.

Current learning theories which situate learning in a social context, link community building with collaborative activity. Collaboration is highly task-dependant as it usually means replacing emotive and usually fragmented social communication with a purposeful and target-oriented one. Tasks which involve elements of collaboration, "apart from driving conceptual work (...) are active, participatory and meaning-centred" (Hampel, 2006, p. 11). Hampel repeats after Meskill (1999, p. 145) that at the basis of such tasks is appreciation for "various perspectives (...) and differing sorts of contributions on the part of the learners". Importantly, this approach to task design reflects the needs of "heterogeneous language classrooms representing a range of cultures and social educational strata" (Meskill, 1999, p. 145). Online collaborative tasks are in fact the embodiment of what Meskill (1999) termed "multiple ability tasks" that is tasks which address participants' multiple perspectives. Taskinduced collaboration turns learners' emotive social presence to cognitive one, pushing participants to engage in higher-level thinking and more intense meaning negotiation.

Kirschner, Beers, Boshuizen and Gijselaers (2008) warn that not all the tasks are suited to collaboration.

They are often too close (i.e. there is little room in the problem space to discuss), too easy (i.e. it can more efficiently be carried out by one person than by a team), or too controlled (i.e. there is little room for learner initiative (p. 404) 
Related literature links task outcome to the degree of task structure. Jorczak (2008) states that highly structured tasks lessen the group management burden and, as such, lead to more intense on-task activity. Rose (2004, cited in Müller-Hartmann \& Schocker-v.Ditfurth) shows that assigning roles to team members results in greater interconnectedness of students' communication, deeper collective understanding and the increased depth of task processing. On a similar note Appel, Robbins, More and Mullen (2012) explain that lack of task-framed guidance leads to 1) language avoidance with participants sticking to well familiar language rather than attempting complex structures; 2) lack of topic for conversation.

\section{Tasks and tools}

The rapidly growing mass of tools and applications brings to the fore the issue of technology affordances and their role in task design (see Doughty \& Long, 2003; Hampel, 2006; Lai \& $\mathrm{Li}, 2011)$. Despite popular attempts to simply transfer F2F tasks to online environments without adjusting them to the new environment (Hampel, 2006), the impact of tool mediation on the process and format of meaning creation is already well acknowledged. Various tools and environments have their unique constraints and potentials which are reflected in task execution, the communication it involves and the shape of the task outcome (see Lai \& Li 2011 for a research overview). As Hauck and Youngs (2008) have it, the modes that tools offer are specific to a particular environment and "their affordances determine how such applications can be used" (Hauck \& Youngs, 2008, p. 7). They continue that "individual affordances create distinct learning environments allowing for different levels of interaction" (Ibid., p. 20).

In IOEs the idea of a task/activity has evolved towards a complex perception of a mode in action which is always mediated by culturally and historically produced and communicated tools and signs (Thorne, 2003). The idea underlies the active relationship between a subject and a tool. In this context the concept of affordances and their perception (see Gibson, 1977) is well grounded: the properties of tools need to be first realised and noticed to inform their uses, pedagogical ones being no exception. Although originally tool affordances were seen as universal, in the current view they are culturally and historically grounded and, as such, unique to a particular community of users (Gaver, 1991; Thorne, 2003). This concept works particularly well in case of complex technologies and environments whose multiple and usually hidden affordances may not be perceptionally 
detected or become subject to cultural interpretation and therefore need to be overtly explored.

Importantly, the pedagogical value of affordances, or pedagogical affordances as they can be termed, does not guarantee effective learning. Rather, they call for "careful planning and a thorough understanding" (McLoughlin \& Lee, 2007, p. 667). Hampel asserts we

have to ensure that tasks are appropriate to the medium used and (...) take into account the affordances (i.e. the constraints and possibilities for making meaning) of the modes available. (Hampel, 2006, p. 111)

In other words, the pedagogy of a tool is not inherent to the tool itself but results from the pedagogical goals which it is to serve, with this relationship being reciprocal. Wang (2007) recommends that task design should start with the evaluation of available tools to assure their appropriateness for the task at hand and to adjust the task accordingly. Referring to videoconferencing contexts, Wang (Ibid.) also recommends a familiarisation stage during which learners can tame unknown tools without being burdened with the cognitive load of other challenges, which is also suggested by Hampel (2006). A tool-oriented preparation is needed to avoid an adverse affect of technology on students' communication since, when confronted with lack of transparency or technical problems, learners may either transfer their interactions to a different channel or environment or withdraw from communication. Technology-oriented training may also alleviate differences resulting from the fact that learners might be accustomed to different culturally and historically grounded uses of technologies (Thorne, 2003).

\section{Preparing teachers for CLE task design}

Successful task design for complex online environments depends to a large extent on teacher's knowledge and awareness of available technology affordances and limitations, as teachers need to analyse and consider which of them can assist the learner in achieving learning objectives and what task demands will best address them (Gonzalez-Lloret, 2014). Importantly, teachers need to be able to notice not only the general affordances of the available technologies but also pedagogical ones and, by making informed pedagogical choices, harness them to serve intended learning objectives. It is only in that way that teachers - task designers can make fully informed pedagogical choices, integrate them smoothly with task objectives and become creative and autonomous designers of educational situations rather than "receivers of pre-packaged content" (Meskill \& Anthony, 2014, p. 178). 
True as the above is, the centeredness of tasks in computer-enhanced online pedagogy may not align with teacher's readiness to embark on task design. The previous focus of CALL-oriented teacher training was on the production of materials and the use of ready-made software. Besides, the dominant shape of majority of CALL teacher training is that of standalone tool-oriented courses which function as add-ons to mainstream academic programmes (Hubbard, 2008, Peters, 2006; Desjardins \& Peters, 2007). Such programmes typically lack integration with other academic courses nor do they provide sufficient exposure to pedagogically sound uses of technology (Brown \& Warschauer, 2006). Moreover, the usual source of confusion for teacher trainees is that their understanding of what a task is comes from their long-time experience (as participants) in traditional in-class instruction whereas their experience of online learning is either non-existent or very limited. In a similar vein, teachers' perception of what a task is can be culturally grounded and reflect the models they have been accustomed to, especially if teacher trainees come from "hierarchical and instructivist learning contexts" (Hampel, 2006:112). Dooly (2010) confirms the need for developing skills in design, implementation and critical assessment of tasks for online collaboration.

There is agreement that training teachers for online task design can be greatly facilitated if task design itself is both practiced and, above all, experienced in a learning environment (Müller-Hartmann 2006, O’Dowd, 2015) This can be done in the complex experiential environment of IOEs where tasks serve as models for participants' own competence and where teacher trainees can experience the affordances and constraints of tasks and their technologies in practice. Since the practice of designing tasks tends to reflect teachers' own pedagogical views, beliefs and experiences, Müller-Hartmann (2006) argues that "teacher educational programmes need to develop both the knowledge base and the belief system, facilitating their interaction and integration" (p. 65). In the process, teacher trainees 1) develop their own understanding of task design, 2) create their own teaching routines, and 3) are likely to incorporate the new competences into their belief system (Müller-Hartmann, 2006, pp. 66-67).

\section{Conclusion}

The preceding sections presented a number of areas connecting to the concept of designing tasks for complex learning environments of telecollaborative exchanges. As O’Dowd puts it 
telecollaboration is undoubtedly one of the most complex aspects for in-service teachers to master due to the combination of organisational and pedagogical competences and technological skills, which are required to successfully set up, run, and integrate a telecollaborative project. $(2015$, p. 64)

In such complex learning contexts, the role of tasks as the main organizational units is particularly pronounced. They serve as powerful scaffolds which 1) providing structure to an ill-structured situation 2) voice the teaching presence; 3) scaffold the learning process; 4) support group cohesion and social presence; 5) turn social activity into cognitive one. Considering that complex learning environments will be becoming both increasingly common and increasingly complex, the success of computer-mediated education will be increasingly determined by how proficient instructors - the pivotal players of new learning environmentswill be at framing them with well designed tasks.

\section{Bibliography}

Anderson, T., Rourke, L., Garrison, D., \& Archer, W. (2001). Assessing teaching presence in a computer conferencing context. Journal of Asynchronous Learning Networks, 5 (2): 1-17. Retrieved 10th March 2015 from : http://cde.athabascau.ca/coi_site/documents/Anderson_Rourke_Garrison_Archer_Tea ching_Presence.pdf

Appel, Ch., Robbins, J., More, J., \& Mullen, T. ( 2012). Task and tool interface design for L2Speaking Interaction Online. In L. Bradley \& S. Thouesny (Eds) CALL: Using, learning, knowing. EUROCALL Conference, Gothenburg, Sweden 22-25 August, Proceedings (pp.15-19). Research-publishing.net: Dublin.

Belz, J. A. (2002). Social dimensions of telecollaborative foreign language study. Language Learning \& Technology, 6(1): 60-81. Retrieved 3rd May 2015 from http://llt.msu.edu/vol6num1/belz/

Breen, M. (1987). Learner contribution to task design. In C. N. Candlin \& D. Murphy (Eds.), Language learning tasks. Vol. 7 (pp. 23-46). London: Prentice-Hall International.

Brown, D., \& Warschauer, M. (2006). From the university to the elementary classroom: Students' experiences in learning to integrate technology in instruction. Journal of Technology and Teacher Education, 14(3): 599-621. Retrieved 3rd May 2015 from http://www.education.uci.edu/person/warschauer_m/docs/integrate.pdf

Candlin, C. N., \& Murphy, D. (Eds.) (1987). Language learning tasks. Englewood Cliffs, NJ: Prentice-Hall International.

Chapelle, C.A. (2001). Computer applications in second language acquisition. Cambridge: Cambridge University Press.

Chen, C. C., Wu, J., Yang, S. C., \& Tsou, H.-Y. (2008). Importance of diversified leadership roles in improving team effectiveness in a virtual collaboration learning environment. Educational Technology \& Society, 11(1): 304-321. Retrieved 3rd May 2015 from http://www.ifets.info/journals/11 1/22.pdf

Cilliers, P. (1998). Complexity and postmodernism. London: Routledge.

Dervin, F. (2014). Exploring 'new' interculturality online. Language and Intercultural Communication, 14(2): 191-206. http://dx.doi.org/10.1080/14708477.2014.896923

Desjardins, F., \& Peters, M. (2007). Single-course approach versus a program approach to develop technological competencies in preservice language teachers. In M.A. Kassen, 
R.Z. Lavine, K. Murphy-Judy \& M. Peters (Eds.) Preparing and developing technology-proficient L2 teachers (pp. 3-21). San Marcos, TX: CALICO Publications.

Dooly, M. (2008). Telecollaborative Language Learning. Bern: Peter Lang.

Dooly, M. (2011). Divergent perceptions of telecollaborative language learning tasks: Tasksas-workplan vs. task-as-process. Language Learning \& Technology, 15(2): 69-91. Retrieved 30 th September 2014 from http://ltt.msu.edu/issues/june2011/dooly.pdf

Dooly, M., \& O'Dowd, R. (Eds.) (2012). Researching online foreign language interaction and exchange: Theories, methods and challenges. Bern/Wien: Peter Lang.

Dundis, S., \& Benson, S. (2003). Building more effective virtual teams: An examination of the task variable in online-group problem-solving. International Journal on ELearning, 2(4): 24-38. Retrieved 20th March 2015 from http://tinyurl.com/ocjyq93

Ellis, R. (2003). Task-based language learning and teaching. Oxford: Oxford University Press.

Doughty, C., \& Long, M. (2003). Optimal psycholinguistic environments for distance foreign language learning. Language Learning \& Technology, 7(3): 50-80. Retrieved 5th Marh 2014 from http://lit.msu.edu/vol7num3/doughty/

Furstenberg, G. (1997). Teaching with technology: What is at stake? ADFL Bulletin, 28(3), $21-25$.

Garrison, D. R. (2006). Online collaboration principles. Journal of Asynchronous Learning Networks, 10(1): 25-34.

Gaver, W. (1991). Technology affordances. In Proceedings of the SIGCHI Conference on Human Factors in Computing Systems 1991 (pp. 79-84). New York: ACM Press.

Gibson, J. (1977). The theory of affordances. In R. Shaw \& J. Bransford (Ed.) Perceiving, acting, and knowing (pp. 67-82). Lawrence Erlbaum.

González-Lloret, M., \& Ortega, L. (2014). Technology-mediated TBLT: researching technology and tasks. Amsterdam: John Benjamins.

Gruba, P. (2004). Designing tasks for online telecollaborative language learning. Prospect, 19(2): 72-81.

Guth, S., \& Helm, F., (Eds.) (2010). Telecollaboration 2.0: language, literacy and intercultural learning in the 21st century. Bern: Peter Lang.

Hampel, R. (2006). Rethinking task design for the digital age: A framework for language teaching and learning in a synchronous online environment. ReCALL, 18(1): 105-121. Retrieved 15th May 2013 from http://oro.open.ac.uk/5419/ .

Hampel, R. (2010). Task design for a virtual learning environment in a distant language course. In M. Thomas \& H. Reinders (Eds.) Task-based language learning and teaching with technology (pp. 131-153). London: Continuum Publishing.

Hauck, M. (2010). The enactment of task design in tellecollaboration 2.0. In M. Thomas \& H. Reinders (Eds.) Task-based language learning and teaching with technology (pp. 197217). London: Continuum.

Hauck, M., \& Youngs, B. (2008). Telecollaboration in multimodal environments: The impact on task design and learner interaction. Computer Assisted Language Learning, 21(2), $87-124$.

Helm, F. (2013). A dialogic model for telecollaboration. Bellaterra Journal of Teaching and Learning Language \& Literature, 6(2): 28-48. Retrieved 5th June 2015 from https://ddd.uab.cat/pub/jt13/jt13_a2013m5-6v6n2/jt13_a2013m5-6v6n2p28.pdf

Helm, F., \& Guth, S. (2010). The multifarious goals of telecollaboration 2.0: Theoretical and practical implications. In S. Guth, \& F. Helm (Eds.) Telecollaboration 2.0: Language, literacy and intercultural learning in the 21st century (pp. 69-106). Bern: Lang. 
Hubbard, P. 2008. CALL and the future of language teacher education. CALICO Journal 25(2): 175-188.

Human-Vogel, S., \& Bouwer, C., (2005). Creating a complex learning environment for the mediation of knowledge construction in diverse educational settings. South African Journal of Education, 25(4): 229-238.

Jauregi, K., Canto, S., de Graaff, R., Koenraad, T., \& Moonen, M. (2011) Verbal interaction in Second Life: towards a pedagogic framework for task design. Computer Assisted Language Learning, 24 (1): 77-101.

Jorczak, R.L. (2008). The effects of task characteristics in higher-order learning in online collaborative learning. Unpublished doctoral dissertation. Retrieved on 2nd June 2015 from http://tinyurl.com/ppvuffh

Kassen, M. A., Lavine, R. Z., Murphy-Judy, K., \& Peters, M. (2007). Preparing and developing technology-proficient L2 teachers. Computer Assisted Language Instruction Consortium (CALICO), Retrieved 18 June 2014 from https:www.calico.org/page.php?id=411

Kirschner, P. A., Beers, P. J., Boshuizen, H. P. A., \& Gijselaers, W. H. (2008). Coercing shared knowledge in collaborative learning environments. Computers in Human Behavior, 24: 403-420. http://dx.doi.org/10.1016/j.chb.2007.01.028

Kress, G., Jewitt, C., Osborne, J., \& Tsatsarelis, C. (2001). Multimodal teaching and learning: The Rhetorics of the science classroom. London and New York: Continuum.

Kupczynski, L., Ice, P., Wiesenmayer, R., \& McCluskey, F. (2010). Student perceptions of the relationship between indicators of teaching presence and success in online courses. Journal of Interactive Online Learning, 9(1): 23-43. Retrieved 3 June 2015 from http://www.editlib.org/p/109406/

Kurek, M., \&. Müller-Hartmann, A. (forthcoming). Task design for telecollaborative exchanges: in search for new criteria. System.

Lai, C., \& Li, G. (2011). Technology and task-based language teaching: A critical review. CALICO Journal, 28(2): 498-521. http://dx.doi.org/10.11139/cj.28.2.498-521

Lamy, M.-N. (2007). Interactive task design: Metachat and the whole language learner. In P. García Mayo (Ed.) Investigating tasks in formal language learning (pp. 242-264). Clevedon, UK: Multilingual Matters.

Lantolf, J., \& Thorne, S. (2006). Sociocultural theory and the genesis of second language development. Oxford: Oxford University Press.

Levy, M., \& Stockwell, G. (2006). CALL dimensions: Options and issues in computer assisted language learning. New Jersey: Lawrence Erlbaum \& Associates.

Long, M. H. (2000). Focus on form in task-based language teaching. In R. L. Lambert \& E. Shohamy (Eds.) Language policy and pedagogy (pp. 179-192). Philadelphia: John Benjamins.

Meskill, C. (1999). Computers as tools for sociocollaborative language learning. In K. Cameron (Eds.) Computer assisted language learning (CALL): media, design and applications (pp. 141-162). Lisse: Swets \& Zeitlinger.

Meskill, C., \& Anthony, N. (2014). Managing synchronous polyfocality in new media/new learning: Online language educators' instructional strategies. System, 42: 177-18.

McLoughlin, C., \& Lee, M. (2007). Social software eand participatory learning: Pedagogical choiceswith technology affordances in the Web 2.0 era. In ICT: Providing choices for learners and learning. Presented at the Ascilite Conference, Singapore. Retrieved 9 June 2015 from http://www.ascilite.org.au/conferences/singapore07/procs/mcloughlin.pdf 
Mishra, P., \& Koehler, M. J. (2006). Technological pedagogical content knowledge: A new framework for teacher knowledge. Teachers College Record, 108(6): 1017-1054.

Müller-Hartmann, A. (2000). The role of tasks in promoting intercultural learning in electronic learning networks. Language Learning \& Technology, 4(2): 129-147. Retrieved 10th October 2011 from http://1t.msu.edu/vol4num2/muller/

Müller-Hartmann, A. (2006). Learning how to teach Intercultural Communicative Competence via telecollaboration: a model for language teacher education. In J.A. Belz \& S. Thorne (Eds.) Internet-mediated intercultural foreign language education (pp. 63-84). Boston: Heinle \& Heinle.

Müller-Hartmann, A. (2007). The teacher role in telecollaboration: Setting up and managing exchanges. In: R. O’Dowd (Ed.) Online intercultural exchange. An introduction for foreign language teachers (pp. 167-192). Clevedon: Multilingual Matters.

Müller-Hartmann, A., \& Schocker-v. Ditfurth, M. (2010). Research on the use of technology in task-based language teaching. In M. Thomas \& H. Reinders (Eds.) Task-based language learning and teaching with technology (pp. 17-40). London: Continuum.

Müller-Hartmann, A., \& Schocker-v. Ditfurth, M. (2011). Teaching English: Task-supported language learning. Paderborn: Schöning.

Nunan, D. (2004). Task-based language teaching. Cambridge: Cambridge University Press.

O'Dowd, R. (2005). Negotiating sociocultural and institutional contexts: The case of SpanishAmerican telecollaboration. Language and Intercultural Communication, 5(1): 40-56. http://dx.doi.org/10.1080/14708470508668882

O'Dowd, R. (2006). Telecollaboration and the development of intercultural communicative competence. Berlin: Langenscheidt.

O'Dowd, R., \& Eberbach, K. (2004). Guides on the side? Tasks and challenges for teachers in telecollaborative projects. ReCALL, 16(1): 5-19.

O'Dowd, R. (2015). Supporting in-service language educators in learning to telecollaborate. Language Learning \& Technology, 19 (1): 63-81. Retrieved 5th June 2015 from http://lit.msu.edu/issues/february2015/odowd.pdf

O'Dowd, R., \& Ritter, M. (2006). Understanding and working with 'failed communication' in telecollaborative exchanges. CALICO Journal, 23: 623-642.

O’Dowd, R., \& Ware, P. (2009). Critical issues in telecollaborative task design. ComputerAssisted Language Learning, 22(2): 173-188. Retrieved 10th October 2011 from http://tinyurl.com/nuppx $8 \mathrm{f}$

Ortega, L. (2009). Interaction and attention to form in L2 text-based computer-mediated communication. In A. Mackey \& C. Polio (Eds.) Multiple perspectives on interaction (pp. 226-253). New York: Routledge.

Oskoz, A., \& Elola, I. (2014) Promoting FL collaborative writing through the use of Web 2.0 tools. In M. Lloret \& L. Ortega (Eds.) Technology and tasks: Exploring technologymediated TBLT (pp. 115-147). Philadelphia, PA: John Benjamins.

Peters, M. (2006). Developing computer competencies for pre-service language teachers: Is one course enough? In P. Hubbard \& M. Levy (Eds.) Teacher education in CALL (pp. 153-165). Amsterdam: John Benjamins.

Robinson, P. (2001). Task complexity, cognitive resources, and syllabus design: A triadic framework for examining task influences on SLA. In P. Robinson (Ed.) Cognition and second language instruction (pp. 285-317). Cambridge, England: Cambridge University Press.

Robinson, P. (2011). Second language task complexity: Researching the cognition hypothesis of language learning and performance. Amsterdam: John Benjamins. 
Rose, M.A. (2004). Comparing productive online dialogue in two-group styles: Cooperative and collaborative. The American Journal of Distance Education, 18(2): 73-88. http://dx.doi.org/10.1207/s15389286ajde1802_2

Samuda, V., \& Bygate, M. (2008). Tasks in second language learning. New York: Palgrave Macmillan.

Shea, P., Li, C., \& Pickett, A. (2006). A study of teaching presence and student sense of learning community in fully online and web-enhanced college courses. Internet and Higher Education, 9 (3): 175-190. http://dx.doi.org/10.1016/j.iheduc.2006.06.005

Skehan, P., \& Foster, P. (2001). Cognition and tasks. In P. Robinson (Ed.) Cognition and second language instruction (pp. 183-205). Cambridge: Cambridge University Press.

Thomas, M., \& Reinders, H. (2010). Task-based language learning and teaching with technology. Philadelphia: John Benjamins Publishing Company.

Thorne, S. L. (2003). Artifacts and cultures-of-use in intercultural communication. Language Learning \& Technology, 7(2): 38-67 Retrieved 20th March, 2014 from http://lit.msu.edu/vol7num2/thorne .

Van den Branden, K. (2006). Task-based language education. From theory to practice. Cambridge: Cambridge University Press.

Wang, Y. (2007). Task design in videoconferencing-supported distance language learning. CALICO Journal, 24(3): 591-630. Retrieved 15th November, 2014 from https://www.calico.org/html/article 662.pdf

Ware, P., \& O'Dowd, R. (2008). Peer feedback on language form in telecollaboration. Language Learning \& Technology, 12(1), 43-63. Retrieved 22 January 2011, http://lit.msu.edu/vol12num1/pdf/wareodowd.pdf

Willis, J. (1996). A framework for task-based learning. Harlow: Addison Wesley Longman.

\section{Author information:}

Malgorzata Kurek is a researcher and lecturer long involved in academic-level intercultural online exchanges. She is currently employed as an Assistant Professor at Institute of Foreign Languges, Jan Dlugosz University, Czestochowa, Poland where she is a lecturer and TEFL trainer. He major research interests include intercultural learning, task design in CALL, FL multiliteracy and CALL teacher preparation. She is an author of ICTenhanced courses for teachers and teacher trainees, as well as several publications in the field of ComputerAssisted Language Learning.

Email: gkurka@gmail.com

To cite this article:

Kurek, M. (2015). Designing tasks for complex virtual learning environments. Bellaterra Journal of Teaching \& Learning Language \& Literature, 8(2), 13-32. DOI: http://dx.doi.org/10.5565/rev/jt13.633

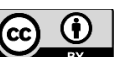

